\title{
Gedagtes oor die begin van die kerk - 'n geskiedenis van versoenende verskeidenheid
}

\author{
AG van Aarde
}

\begin{abstract}
Thoughts on the beginnings of the church as a history of reconciliating diversity

Against the backdrop of the beginnings of the church, the article makes a plea for modern believers to take the humanity of the church more seriously in their forming of ecclesiastical structures. The development of the concept 'church unity' in the New Testament was part of the attempt to establish firstly continuation in the Jesus-movement and secondly mutual fellowship among the conflicting Jewish and Hellenistic Christians during the very beginnings of the church in the first century. Thoughts on the beginnings of the church, therefore, should not be from the perspective of institutional unity but from reconciliating diversities. Modern ideas regarding the unity of the church originated from the latetwentieth century philosophy of holism and shouldn't be anachronistically seen as the concretisation of a Biblical idea.
\end{abstract}

\section{TESE EN UITGANGSPUNT}

Daar is ' $n$ gees van ekumeniese ongeduld in ons dag vaardig wat die opbou van die kerk nie dien nie. Die drang tot kerklike eenheidstrukture stry teen dit wat in die Nuwe Testament en in die ander literatuur van die vroegste kerk gelees kan word oor die begin van die kerk. Hierdie ywer vir eenheid ontneem die kerk sy menslikheid deurdat dit die kerk wil laat opgaan in 'n illusionêre superstruktuur bestaande uit supermense. Dit verwar die uitdrukking 'eenheid in die geloof' met die on-menslike eendersheid-van-mense-idee en dit laat die begrip 'gemeenskap van heiliges' opgaan in 'n 'gemeenskap van hemelinge'.

\footnotetext{
* Voordrag by geleentheid van die Fakulteit Teologie (Afdeling A), van die Universiteit van Pretoria, se teologiese aktualiteitsdag op Donderdag 21 Mei 1987.
} 
Sodoende word uit die oog verloor dat Jesus as gelykenisverteller die koninkryk van God in terme van die mensewêreld geilllustreer het en nie omgekeerd die mensewêreld na analogie van die hemelse nie.

Karl Barth se verduideliking van die uitdrukking 'God as die GansAndere' op 25 September 1956 in 'n rede getitel, Die Menschlichkeit Gottes, is daarom vir ons doeleindes belangrik. In dié rede [alleen in sy Engelse vertaling (1972) tot my beskikking - AG v A] het Barth teruggekyk op sy eie teologiese besinning waarin hy God sedert 1920 teenoor die liberale teologie as die Gans-Andere wou beklemtoon en die mens as die miserabele. Hierin is hy deur sekere mense verkeerd verstaan, het Barth (1972: 45) gesê. Hy het nooit bedoel om God in absolute terme, geïsoleerd en los van die mens te sien nie.

In Jesus Christ there is no isolation of man from God or of God from man. Rather, in Him, we encounter the history, the dialogue, in which God and man meet together and are together, the reality of the covenant mutually contracted, preserved, and fulfilled by them (Barth 1972: 46; beklemtoning deur Barth).

Maar, het Barth (1972: 62) toegevoeg, hy moet toegee dat wat die kerk betref, hy daaraan skuldig was om mens-ontwykend daaroor te teologiseer. Hy het die fout gemaak om die teologiese relevansie van die kerk alleen te sien as die negatiewe menslike teenpool teenoor die koninkryk van God. Hy sou hom in hierdie verband eerder in die geselskap van Rudolf Bultmann se teologiese eksistensialisme wou sien deur vas te hou aan dié waarheid dat ons nie oor God kan praat anders as om ook oor die mens te praat nie (Barth 1972:56).

... in the knowledge of the humanity of God one must take seriously, affirm, and thankfully acknowledge Christendom, the Church. We must, each in his place, take part in its life and join in its service. It was part of the exaggerations of which we were guilty in 1920 [dié jaar waarin Barth hom teenoor Adolf von Harnack as liberale teoloog gerig het - AG v A] that we were able to see the theological relevance of the Church only as a negative counterpart to the Kingdom of God which we had then so happily rediscovered. We wanted to interpret the form of the Church's doctrine, its worship, its juridical order as 'human, all too human', as 'not so important'. We regarded all the earnestness or even zeal devoted to them as superfluous or even injurious. In all this we at least approached the theology and practice of a spiritual partisanship and an esoteric gnosticism .... And it certainly was and is no 
good undertaking to reverse the sequence whereby event precedes institution, which is also established by the entire Bible (Barth 1972: 62-63; beklemtoning deur Barth).

In die lig van my verstaan van die begin van die kerk in die eerste eeue van ons jaartelling, lewer ek 'n pleidooi vir die menslikheid van die kerk. Ek verstaan die spore in die Nuwe Testament van 'n ontwikkeling van 'n eenheid-van-die-kerk-begrip as aanduidinge van die eis om enersyds kontinuïteit in die oordra van die evangelie en andersyds die onbelemmerende gemeenskap van die gelowigies. Alleen so gesien, kan die funksionaliteit van die kombinasie van die begrippe 'eenheid' en 'algemeenheid' wat in die periode van die kerkvaders vorendag gekom het, begryp word.

Die feit dat die kerkvaders reeds vroeg in die kerkgeskiedenis die algemeenheid van die kerk bely het, vooronderstel dat die kerk oor die spektrum van plekke en situasies verspreid geraak het. 'Algemeenheid' vooronderstel dus 'veelheid' - veelheid van gemeentelike lokaliserings; veelheid van lewenssituasies; veelheid van mense in die kerk; veelheid van kerke. Dit is nie 'n 'algemeenheid' ten spyte van 'die veelheid' nie, maar op grond van die 'veelheid'. Una sancta ecclesia kom nie neer op uniformitas sancta ecclesia nie. Dis soos die emeritus-professor in die Nuwe-Testamentiese Wetenskap, Oscar Cullmann, in 1986 in sy boek Einheit durch Veilfalt skryf:

Um diese Verwechslung zu vermeiden, müssen wir die Einheit präzisieren als 'Einheit in der Vielheit', wobei Veilheit nicht nur quantitativ, sondern auch qualitativ im Sinne von Verscheidenheit zu verstehen ist (Cullmann 1986: 15-16).

Cullmann (1986: 141-142) sê dat die hedendaagse ekumeniese eenheidsverlange ' $n$ illusie is - dit is ' $n$ verwagting wat nie gerealiseer het in die Nuwe-Testamentiese periode of in ons eie tydvak nie; dit is ' $n$ verwagting wat in die toekoms ook nie kan realiseer nie, want so 'n verlange verwag van die kerk om 'n superkerkstruktuur daar te stel waarin mense wat nie mense mag wees nie, kerk moet wees.

Cullmann is 'n Lutheraan, maar dieselfde pleidooi vir 'n menslike kerk, hierdie keer met betrekking tot die ampstruktuur in die besonder, kom van die Rooms-Katolieke dogmatikus, Edward Schillebeeckx, wat in 1985 sy boek Pleidooi voor mensen in de kerk skryf. Hy maan daarteen dat die kerklike strukture nie mens-onderdrukkend moet wees nie, want dit weerspreek die Gees van Jesus (kyk Blei 1986: 10-13). 
Bouke Spoelstra, Gereformeerde ekklesioloog hier te lande, bevind hom in dieselfde geselskap. Ook hy toon instemming met ' $n$ ander Rooms-Katoliek, naamlik Hans Küng, wat nie aan die kerk primêr in terme van 'n abstrakte struktuur wil dink nie. Die kerk is vir Küng in die eerste plek 'mense' (kyk Spoelstra 1986: 100-101). Spoelstra (1986: 98) noem die gedurige vrymaak van 'valse kerke' deur Gereformeerde kerke in Nederland (en in Suid-Afrika) 'n 'skouspel'.

'Kerk' word duidelik in abstrakte sin as struktuur, vorm of instituut verstaan wat op sigself holus bolus waar of vals is. 'n Kerk is dus soos ' $n$ motorkar wat padwaardig is of afgeskryf moet word indien dit ' $n$ paar kruisies op die kaart van die padwaardigheidsinspekteur kry. Hierdie formele strukturele kerkbegrip is volkome mensloos (Spoelstra 1986: 98).

Tog het dit vanuit die vroegste kerkgeskiedenis alte gou geblyk dat die kerk sonder institusionalisering ook nie denkbaar is nie. Toe die instituut egter ' $n$ ideële grootheid geword het, is die mense in die kerk op die agtergrond gestoot en deur abstrakte strukture vervang. Die tipe 'hiërargiese' struktuur wat die Nederlandse Geloofsbelydenis in Artikel 32 toelaat onder die ampsdraers in die kerk, is dat dié bepaalde orde en kerkstruktuur diensbaar moet wees om die 'eendrag en eenheid' van die mense in die kerk 'te bevorder en te bewaar'.

In die geledere van die Nederduitsch Hervormde Kerk maan prof Pont reeds lankal dat die strukture in die kerk nie 'n doel op sigself moet wees nie. In 'n resente artikel trek hy die onderskeid tussen die begrippe 'sigbare kerk' en 'onsigbare kerk' in hierdie verband in die debat in en verduidelik dié onderskeid aan die hand van die begrippe 'verbond' en 'uitverkiesing' (Pont 1987: 42-43). Op die voetspoor van Calvyn wil hy die begrippe 'sigbare kerk' en onsigbare kerk' van mekaar onderskei, maar nie skei nie. Dit lyk nie vir my dat Pont met die begrip 'onsigbare kerk' dit in die oog het wat Van Selms (in Van Wyk 1978: 64) vroeër beweer het en Andries Botha (1987: 122) weer onlangs kwytgeraak het oor teoloë wat die 'beginsel van verskeidenheid' sou beklemtoon nie. In Pont (1987) se artikel vind ek nie spore van 'n teoloog se verleentheidsvlug om sy gewete oor die 'verskeidenheid van die kerk' tot rus te wil laat kom nie (Van Selms, in Van Wyk 1978: 64) of van 'n vervlugting van die 'eenheid van die kerk' in 'n abstrakte idee nie (Botha 1987: 122). Pont (1987: 43) wil tereg op grond daarvan dat 'verbond' en 'uitverkiesing', en korrelerend hiermee 'kerk' en 'koninkryk', nie verwar moet word nie, die 'verbond' sien as die 'empiriese 
grondslag van die kerk... soos hy hom in die wêreld openbaar'. As ek dit reg verstaan, wil Pont sê dat God se uitverkiesende handeling met die mens in sy verbond met die mens realiseer en die kerk is hiervan die empiriese gevolg. Van Selms (in Van Wyk 1978: 64) het reg as hy sê dat die begrippe 'sigbare kerk' en 'onsigbare kerk' by Calvyn betrekking gehad het op die voorstelling van die kerk as corpus permixtum dit wil sê bestaande uit sowel 'waaragtige gelowiges' as 'skynheilige gelowiges', 'n spanning wat ten diepste in die wese van elke kerklidmaat aanwesig is. Maar dis presies wat Pont (1987: 37) ook sê:

In die Calvinistiese kerk, wat 'n verbondskarakter dra, is en bly die kerk 'n corpus permixtum wat dus nooit 'n suiwer kerk kan wees nie, want verbond en uitverkiesing val nié saam nie.

Dis waarom 'sigbare kerk' en 'onsigbare kerk', soos 'kerk' en 'koninkryk', van mekaar onderskei, maar nie van mekaar geskei word nie. Dis eerder ' $n$ dialektiese relasie en korreleer met wat Karl Barth (vgl verwysing en aanhaling vroeër in die artikel) bedoel het toe hy gesê het dat die kerk nie die negatiewe menslike teenpool van die koninkryk van God is nie. Juis op grond van die menswording van Jesus Christus - die 'vervulling van die verbond' (Barth 1960: 154-155) - het God deur sy Gees in en deur die koninkryksbeslissings van die kerk sy koninkryk sigbaar in die wêreld laat word (kyk later). Die kerk is nie sigbaar as daar bloot êrens 'n kerklike struktuur as sodanig bestaan nie. Die kerk is sigbaar daar waar koninkryksbeslissings geneem word. Tog moet 'geloof' en 'werke' nie verwar word nie. Eersgenoemde gaan laasgenoemde vooraf, soos in dogmatiese terme die 'uitverkiesing' die 'verbond' voorafgaan en eersgenoemde in laasgenoemde uitmond. Dit gebeur deur die werk van die Heilige Gees en die verkondiging van die Woord. Vanweë die onlosmaaklikheid van Woord en Gees het institusionalisering baie gou in die vroegste kerk 'n aanvang geneem. Kerkstrukture is derhalwe middele tot ' $n$ doel.

Dit is tog belangrik om daarop te let dat by Calvyn die kerk ' $n$ lewende organisme is met 'n organisatoriese kant en dat die struktuur ' $n$ middel tot ' $n$ doel is. Die groot doel van die kerk is om draer van die waarheid van die Woord te wees om so alles en almal op te roep om tot eer van God te leef en te werk.... Die strukturele is by Calvyn nooit absoluut nie omdat die struktuur tot die welwese van die kerk behoort en nié tot die wese van die kerk nie. Wat nie wil sê dat die struktuur onbelangrik is nie, maar dat dit nie ' $n$ doel in sigself is nie (Pont 1987: 43-44). 
So gesien is die Rooms-Katolieke, Schillebeeckx en Küng, se pleidooi vir ' $n$ meer menslike Rooms-Katolieke Kerk nie ver verwyder van wat die hervormers met die opstel van Artikels 31 en 32 van die Nederlandse Geloofsbelydenis in die oog gehad het nie, en gebruik hulle in hierdie opsig ook nie ' $n$ ander idioom as Pont en Spoelstra hier te lande nie. Saam met Spoelstra (1986: 106-108) vind ons dat ook die Lutheraan, Cullmann, in sy kritiek op die drang na ekumeniese superkerkstrukture, min of meer dieselfde sê, wanneer hy skryf:

Hauptsache ist, dass die Koinonia als wirkliche Einheit durch Vielfalt zustande komme ... (Cullmann 1986: 111).

Mens moet nie 'n te romantiese voorstelling van die kerk hê nie. Dit geld vir die kerk in die Nuwe-Testamentiese periode en vir die kerk vandag.

Van die kant van die Praktiese Teologie praat dr J Hendriks, direkteur van die Instituut voor Praktische Theologie van die Vrije Universiteit, Nederland, in 'n onderhoud met die Weekbulletin van het Persbureau der Nederlandse Hervormde Kerk, in dieselfde rigting (kyk Hemstede 1987: 8). Hy sê ons het in die kerk die neiging om anders met konflikte om te gaan as in byvoorbeeld die politieke lewe of die bedryfslewe. Hoewel Hendriks die krisispastoraat in die oog het, het die vertrekpunt waaruit hy teologiseer, ook betrekking op die kerkbegrip. Ons, sê hy, hou dikwels ' $n$ wensbeeld van wat kerk is, voor.

De gemeente wordt dan gezien als een gelukkig gezin waar konflikten niet kunnen en mogen bestaan. Konflikten horen bij het leven, dus ook bij een levende gemeente... . Het beeld van de harmonie in een gemeente is niet juist. Het is nog grotere onzin om te zeggen, dat in de kerk de mensen het over alles met elkaar eens dienen te zijn. Je kunt ook één zijn zonder het met elkaar eens te zijn .... Het andere beeld, dat de mensen in de kerk het over alles met elkaar oneens zijn als vrucht van de polarisatie is ook onjuist .... Konflikten horen bij het leven. Dus ook bij de kerk. Als een kerk geen konflikten kent, dan staat het er slecht met die kerk voor. Dan is zij dood (Hendriks, in Hemstede 1987:8).

Wat ek vervolgens beoog, is om eerstens ' $n$ baie kort oorsig te gee van die begin en die ontwikkeling van die begrip 'kerk' in die Nuwe Testament en om die ontwikkeling van die begrip 'amp' binne so 'n geskiedenisgang in 'n voëlvlug te volg; tweedens om 'n baie kort oorsig te bied van die semantiek van die term ekklessia as 'n belangrike 
selfaanduiding van die kerk in die Nuwe Testament. Die geskiedenisbeskrywende aspekte behoort nie tot die Nuwe Testament as kanon ingeperk te word nie, maar behoort die tog tot en met Augustinus te omvat. Wat die ander saak hierbo betref, die semantiese begripstudie, behoort dit nie tot woordeboekanalises beperk te bly nie. Om die betrokke terme se tekstuele funksionaliteit nie uit die oog te verloor nie, behoort die gebruike daarvan in konteks na aanleiding van die resultate van die geskiedbeskrywende aspekte nagegaan te word. Tyd en ruimte laat dit egter nie toe dat dit volledig gedoen kan word nie. 'n Volledige studie behoort ook die ander terme en metafore wat op die kerk in die Nuwe Testament betrekking het, na te gaan.* Tog is die volgende metodologiese opmerkings van belang: Dogmatiese leerbegrippe, soos byvoorbeeld die 'kerk' en die 'ampte', is onder andere in Suid-Afrika te dikwels op 'n skolasties-sistematiese patroon bestudeer. Woorde wat op ' $n$ bepaalde begrip in die Nuwe Testament betrekking het, word uitgehaal en op 'n gelykstellende literêre en historiese vlak in 'n somtotaal hanteer. Die historiese meervlakkigheid van situasies en tekstuele interrelasies in die Nuwe Testament is die rede waarom die sistematiese studie van leerbegrippe nie ongekompliseerd is nie. En dan is die probleem van wat met betrekking tot 'n leerbegrip as kontingent en dus as histories tydgebonde geag moet word of normatief vir die hede is, nie eens in die gesigsveld van ons studie nie.

Die feit dat geen geskiedskrywing moontlik kan wees sonder om te vra na die verband tussen oorsaak en gevolg nie, mag ook nie by die ondersoek na die Nuwe-Testamentiese oorspronge en ontwikkelinge van leerbegrippe geïgnoreer word nie. So byvoorbeeld behoort 'n studie van die kerkbegrip in die Nuwe Testament in ag te neem dat Matteus histories ná Markus is en literêr daarvan afhanklik was; dat Paulus kronologies vóór die evangelies bestudeer moet word, maar dat daar tradisies in die evangelies is wat ouer is as Paulus en dat sommige daarvan teruggaan na Jesus self en ook Ou-Testamentiese aanhalings en toespelinge kan bevat; dat die verkondigende Jesus alleen as die verkondigde Christus geïnterpreteer kan word; dat die voor-pase situasie nie op dieselfde vlak hanteer kan word as die na-pase situasie of die situasie ná die val van Jerusalem in $70 \mathrm{nC}$ nie; dat, wat die evangelies betref, die na-pase situasie in die voor-pase situasie deur-

\footnotetext{
* Die onderhawige studie gaan ook nie in op die verband wat daar in die Nuwe Testament bestaan tussen enersyds die ontwikkeling van die kerkbegrip en andersyds die doop en veral die nagmaal nie (vgl egter onder andere Stendahl 1959: 1305 en Hahn 1986e).
} 
sigtig is en omgekeerd; dat die vertellende Jesus by die redenerende Paulus oorgegaan het in ' $n$ verkondiging van die evangelie oor Jesus; dat daar by Paulus self ' $n$ ontwikkeling in historiese gemeentesituasies veronderstel moet word en dat ' $n$ leerbegrip derhalwe in die Pauliniese korpus 'n verandering kon ondergaan, soos dit inderdaad die geval was ten opsigte van die begrippe 'kerk' en 'amp'; dat die oorgang van die Christelike godsdiens vanuit die Palestynse bodem na die Hellenistiese 'n komplekse ontwikkeling ten opsigte van die kerkbegrip verteenwoordig - byvoorbeeld dat Jodedom en Hellenisme reeds by Jesus self nie kompartementeel skeibaar is nie, maar dat die Helleniseringsproses waaraan die Jode onderwerp was, wel 'n krag was agter die ontwikkeling van die kerkbegrip; en dat die Christelike godsdiens in mindere of meerdere mate tot en met $135 \mathrm{nC}$ in die Jodedom ingebed was (Katz 1984:76; Stark 1986: 314), maar met 'n gedurige konflik tussen kerk en sinagoge en dat laasgenoemde die Christene as 'n politiese beweging gesien het. Politiek en godsdiens was egter onregverdig vermeng deurdat die amptelike Jodedom die Christendom en die gnostiek oor een kam geskeer het (Katz 1984: 55). Om die waarheid te sê, die oorspronge van die kerk en die geestelikheid van sy aard lê hier, in die bedding van die verhouding met die sinagoge. Christopher Rowland het in 'n 1985-publikasie juis aangetoon dat die breuk met die sinagoge teësinnig van die kant van die Christene plaasgevind het. Hy betoog ook dat die andersheid van die Christendom geleë was in onder andere die graduele institusionalisering daarvan op grond van die uitbly van die wederkoms en die tempering in eskatologiese entoesiasme. Die administrasie van regulasies rondom die sakramente en die ampte is hiervan aanduidinge (Rowland 1985: 244). Die Nuwe-Testamentikus, JK Elliot (1987: 149-151), van die University of Leeds, het Rowland hierin gelyk gegee.

Elkeen wat hierdie historiese feite insgelyks toegee, kan nie meer met betrekking tot die kerk teologiseer vanuit die perspektief van 'institusionele eenheid' nie. Soos reeds vroeër gesê, moet die spore in die Nuwe Testament van 'n ontwikkeling van 'n eenheid-van-die-kerk begrip geïnterpreteer word as aanduidinge van die eis om enersyds kontinuitteit in die oordra van die evangelie en andersyds die onbelemmerde gemeenskap van die gelowiges.

\section{DIE BEGIN VAN DIE KERK}

Daar kan nie gepraat word oor die oorsprong, wese en inhoud van die Christendom sonder om die Persoon wat agter dit alles is, die hoofsaak 
te maak nie. Aan die een kant het die aanvang van die kerk 'n eg-menslike karakter. Aan die ander kant staan ons voor die wonder van dié beginpunt. Uiteraard is ' $n$ beginpunt voorwaarde en bepalend vir alles wat daarop volg. Maar juis dit is die rede waarom ' $n$ beskrywing van die historiese beginpunt van die kerk so problematies is. Die gelowige geskiedskrywer staan by hierdie punt voor die wonder van alle wonders, naamlik die menswording van die Seun van God. Die mens Jesus wat uit God is, is die absolute aanvang van die geskiedenis van die kerk. Hier is die eg-menslikheid van die kerk geleë. Vanuit hierdie absolute beginpunt hoef die menslikheid van die kerk nie negatief waardeer te word nie. Die mense wat die kerk uitmaak, is diegene wat hulle heil in Jesus verwag. Dit bring mee dat ons hier met ' $n$ indikatief-imperatief verhouding te doen het: die Nuwe Testament verkondig dat die sondaar-mens wat mens buite-om Christus is, die verlossing moet soek wat in Christus is, en die verloste word nie ' $n$ super-mens nie, maar bly net mens. Dié indikatief-imperatief bly as ' $n$ spanning in kerk-mense bestaan en is ook die rede waarom ons op grond van die Nuwe-Testamentiese getuienis van en oor die volgelinge van Jesus sê dat die menslike kerk nie anders voorgestel kan word as 'n corpus permixtum nie. In dié sin van die woord is die kerk in Karl Barth (1932: 190) se terme: 'heiden-kerk', 'tollenaars-kerk'.

Ons het gesê dat die inkarnasie as die absolute aanvang van die kerk die geskiedskrywing van die begin van die kerk moeilik, indien nie onmoontlik nie, maak. Hierdie wonder staan net soos Jesus se opstanding uit die dood, bo die historiese menslike samehang. Wanneer iemand soos FC Baur (1860: 1-2) een van die eerste Christelike godsdienshistorici, dit aan die historiese ondersoek onderwerp, doen hy dit met die volgende vraag: Waarom en met watter gevolge het hierdie wonder, enersyds van Jesus se menswording en andersyds van sy opstanding, waarmee die geskiedenis van die kerk 'n aanvang geneem en bepalend in 'n rigting ontwikkel het, juis op hierdie punt in die wêreldgeskiedenis plaasgevind?

'n Mens moet begin deur te sê dat die kerk sy toetrede op Joodse bodem gemaak het toe die Romeinse Ryk reeds sy hoogtepunt bereik het. En juis hier waar die absolute éénheid van die kerk lê,, naamlik in sy hoofsaak - Jesus Christus - begin ook die diversiteit.

Die diepste wortels van die Christendom is die monoteïstiese Godsbegrip van die gelowiges in die Ou Testament (Baur 1860: 17). Hierdie kontinuïteit met die Ou Testament kan myns insiens die uitsprake in Artikel 27 van die Nederlandse Geloofsbelydenis en in Sondagsafdeling 
21 van die Heidelbergse Kategismus opvang dat die 'kerk' as die gemeenskap van die gelowiges reeds van die begin van die wêreld daar was. Vóór Christus lê die kerk se wortels in die monoteïstiese Godsbegrip van die gelowiges in die Ou Testament. Waar die Ou-Testamentiese Godsbegrip ingevul is vanuit 'n partikularisties-nasionale perspektief, daar was die invloed van die Hellenisme op die Jodedom met die aanbreek van die Nuwe-Testamentiese periode reeds so sterk dat ons van onder andere 'n Aleksandrynse Jodedom kan praat waar die partikularisme in ' $n$ tipe universalisme oorgegaan het (kyk Aalders 1985: 17-18). Dit is byvoorbeeld in die werk van Philo sigbaar (vgl o a Baur 1860: 19-20).

Kenmerkend van hierdie fase was die ywerige proselietmakery deur die Jode. Philo het die doel daarvan nie gekoppel aan 'n magstrewe wat moes uitloop op die realisering van die messiasryk met die oog op die vernietiging van Israel se vyande nie. Volgens hom wou die Jodedom 'n geestelike sending vervul. Hy het die verhouding waarin die Jodedom tot die ganse mensheid staan, voorgestel as die verhouding tussen die priester en die staat (kyk Aalders 1985: 29-30).

Hierdie oorgang van partikularisme na universalisme moet egter nie as 'n radikale breuk gesien word nie. Dit was nie 'n abrupte loslating van die oue en 'n skielike en onverwagte aanvang van die nuwe nie. In 'n oorgangsfase leef die oue en die nuwe langs mekaar.

Aalders (1985: 95) formuleer dit soos volg:

Zo ontstonden naast de joden de judaïserende christenen en de heidenchristenen, die alle drie dezelfde God beleden, waarover bij de oudchristelijke schrijvers geen meningsverschil bestond. Het grote onoplosbare probleem tussen joden en christenen was Jezus als de preëxistente Christus (my beklemtoning).

Dit was met ander woorde veral die Hellenistiese Christene se voorstelling van Jesus as die preëksistente Seun van God wat nuut was. Die verkondiging van Jesus se menswording en die opstanding as die keersy van sy kruisdood het elemente van hierdie Jesusvoorstelling bevat. Selfs 'n konserwatiewe Nuwe-Testamentikus soos Marshall (1977: 128) kom ten opsigte van die wortels van die Christologie van die Nuwe Testament tot die gevolgtrekking dat the evidence supports the view that it was the resurrection of Jesus which gave the decisive stimulus to Christological thinking'. Hierdie insig is te danke aan die baanbrekerswerk van persone soos Wilhelm Bousset, Wilhelm Heitmüller, Rudolf Bultmann en Ferdinand Hahn oor die verinheemsing 
van die Hellenisme op Palestynse bodem, en die assimilasie en konflikte wat as gevolg daarvan ontstaan het.

Wat hierdie oorgang vanaf die tipies Ou-Testamentiese partikularisme na die universalisme onder Hellenistiese invloed betref, is dit interessant om daarop te let dat die apologete onder die kerkvaders in die patristiese periode dit betekenisvol gevind het dat die Christendom sy verskyning in die wêreldgeskiedenis gemaak het toe die Romeinse Ryk sy hoogtepunt bereik het (kyk Baur 1860: 2). Baur (1860: 8) wys op die volgende verband: Toe die Romeine daarin geslaag het om alle volke van die destydse wêreld onder een politieke heerskappy te verenig, het die Christendom tegelykertyd ook begin uitbrei. Hierdie feit dat al die volke nou onder één heerser te staan gekom het, het die tydsgees van politiese universalisme daargestel. Die Christendom se verspreiding vanaf Judea, na Samaria en Antiogië tot by Rome as die simbool van politieke universalisme het die universalisme van die Romeinse wêreldheerskappy as wesenlike vooronderstelling. Die baie nuwe verkeersweë en ander faktore soos ekonomiese kragte het die uitbreiding van die Christendom in die Romeinse provinsies bevoordeel.

Baur sê dat ons glo dat God in sy voorsienigheid geen beter tyd kon kies om die Christendom in die wêreldgeskiedenis te laat intree nie. Resente studies van Joods-Tannaïtiese geskrifte wat hulle oorsprong gehad het in die na-70 $\mathrm{nC}$ herorganiseerde, amptelike Jodedom in Jamnia (kyk Katz 1984: 47), toon aan dat dit die geloof in die maagdelike geboorte van Jesus was sowel as in sy opstanding wat die Christendom ' $n$ vreemde verskynsel in die Jodedom vanuit die gesigspunt van die amptelike Joodse leiers gemaak het. Hiervan is daar ook sterk aanduidinge in die Nuwe Testament self.

Baie geleerdes het daarop gewys dat waar die messias-idee 'n belangrike aanknopingspunt tussen die Jodedom en die Christendom was, daar het die soort geboorte en die soort dood van Jesus Christus hierdie aanknopingspunt weer opgehef. 'n Dood soos sý dood het dit vir die Jood baie moeilik gemaak om Hom as die Messias te aanvaar. Dit was alleen in en deur die geloof as daad van God moontlik. 'n Lydende en gekruisigde Christus het deur die geloof in die wonder van sy opstanding die kern en vaste grond van die historiese ontwikkeling van die Christendom geword. Hierdie geloof in die wonder van die inkarnasie en in die wonder van die opstanding - en die NuweTestamentiese kerugma daaroor - het die breuk tussen die Christendom en die Jodedom laat toeneem. 'n Belangrike rede daarvoor is dat dit 
in die Tannaitiese literatuur oor dieselfde kam geskeer is as die Joodse en Hellenistiese gnostiek. Dit het weer meegebring dat die Christendom vanuit die gesigspunt van die Joodse sinagogale owerheid, maar ook vanuit die hoek van die Romeinse owerheid, as 'n politieke bedreiging ervaar was. Die opstand van Bar Kochba in $135 \mathrm{nC}$ wat die politieke stryd tussen die Jode en die Romeine in 'n sekere sin tot 'n hoogtepunt gevoer het, het die 'staats'-vervolgde situasie van die kerk ook tot 'n hoogtepunt gevoer. Dis eers opgelos toe die pendulebeweging na universalisme daartoe gelei het dat die Christendom in die vierde eeu staatsgodsdiens geword het. En dit het die Jesus-saak, waarvoor die kerk in die wêreld ingegaan het, nie tot voordeel gestrek nie. Vanuit die Nuwe Testament gesien en vanuit die teenswoordige tyd retrospektief gesien, is die kerk nie maar net die geestelike keersy van die politiek nie.

Hoewel ons Hegel in sy idealistiese geskiedsfilosofie moet gelyk gee dat die mens geneig is tot ' $n$ universele teleologie, tot 'n gees van universalisme - vergelyk byvoorbeeld Aleksander die Grote wat die grense na die Ooste oorgesteek het en die Hellenisme as die nuwe universele kultuur wou vestig - sien ons dat die universalisme nie in staat is om die gees van partikularisme uit te woeker nie. Hegel se geskiedsfilosofie hou juis 'sintese' voor as die eindpunt van die geskiedsbeweging. Die gees van partikularisme is ook nie in die Nuwe Testament self opgehef nie. Inteendeel, partikularisme en universalisme is sedert Jesus deur die Nuwe-Testamentiese skrywers in 'n mindere of meerdere mate gepropageer en gerealiseer as ' $n$ tweeeenheid. Die eenheid-in-die-apostoliese-tradisie, ofte wel die eenheidin-die-geloof-begrip, het verband gehou daarmee dat daar op elke plek waar die Christendom verspreid geraak het, vasgehou is aan die Jesus-saak (vgl o a Ef 4: 1-16). Maar nie sonder die geprofileerdheid van 'n 'Petriniese' in onderskeid met 'n 'Pauliniese' klemtoon nie. Die algemeenheid van die kerk op al sy verskillende plekke het prakties ingehou dat die spontane gemeenskap van gelowiges onbelemmerd moes plaasvind.

Käsemann $(1963 ; 1969)$ het saam met ander Nuwe-Testamentici (kyk o a Hahn 1986d) daarop gewys dat die vroeë katolisisme reeds 'n beweging in die Nuwe Testament was. Maar dat dit in die NuweTestamentiese periode en die periode van die kerkvaders daarna neergekom het op eenheid-in-instituut, is eenvoudig net nie histories aanduibaar nie. Walter Getting onderskryf hierdie historiese feit en hy 
doen dit op grond van sy studie van eerstehandse dokumente wat hulle oorsprong het in die periode vanaf die Nuwe Testament tot $250 \mathrm{nC}$.

The New Testament concept of the church as una sancta [kyk resp Ef 4: 1-6 en 5: 27 - AG v A] continued to have a strong influence on the thinking of the early church. This unity among the various churches in Christendom was assumed, however, rather than organized. There was no administrative structure to which one could point in order to show 'unity'. It was taken for granted that all except the heretics believed the same things and that they were doing the same work. They communicated with each other when difficulties arose; individuals travelled from one church to another as teachers; but there was no organization beyond this (Oetting 1964: 50; my beklemtoning).

So het die kerk dan begin:

As beweging van Jode het hulle in en deur Jesus, God se sorg vir hulle ervaar. Spoedig het dit ook' $n$ beweging van ander geword. Griekssprekende diaspora-Jode is in die Naam van Jesus gedoop en die Gees het ook in hulle harte kom woon. Die Nuwe-Testamentiese geloofsgemeenskap het beheers-deur-die-Gees probeer leef. In so 'n gemeenskap kon leiding en gesagsuitoefening per definisie nie beteken dat die een aan die ander onderworpe is nie. Hierdie situasie het egter verander en die entoesiastiese Christene moes gemaan word om in harmonie, soos ' $n$ simfonie, in liefde met mekaar saam te lewe deur beide voete plat op die aarde te hou. Om as Christene in 'n nog-nie-onverganklike wêreld te lewe, moes hulle hoor dat hulle hulle byvoorbeeld as goeie burgers aan die Romeinse owerheid moes onderwerp en die verpligte belasting aan die tempel moes betaal; hulle moes hulle plek in die huwelik en in die gemeenskap volstaan. Dit het egter in die kerk ' $n$ geestelike bestuurstelsel noodsaaklik gemaak en institusionalisering het gevolg waardeur konflikte soos byvoorbeeld dié tussen Paulus en Petrus hanteer is. Stadigaan ontstaan daar'n ampstruktuur. Wat aanvanklik as Geestesgawes van allerlei bedieninge gesien is, word ' $n$ ampscharisma deur die seremonie van handoplegging in die Naam van Jesus. Met watter doel? Ter wille van die kontinuïteit van die Jesus-saak en ter wille van die eendrag en eenheid in hart en wil onder die verskillende mense en gemeentes verspreid oor baie plekke.

Teen die einde van die eerste eeu was dit al so dat die 'biskop' gesien is as die gevolmagtigde draer van die evangelie van Jesus. Die 'biskop' was die simbool van die eenheid van die kerk. Maar hy was nie die 
simbool van die één georganiseerde en geïnstitusionaliseerde kerk nie; hy was die simbool van die eenheid-in-die-waarheid waarvan hy 'n gelegitimeerde draer is. Oetting verwys na 'n interessante ontwikkeling tussen Ignatius, biskop van Antiogië aan die begin van die 2 de eeu nC, en Cyprianus, biskop van Kartago in die eerste helfte van die 3de eeu $\mathrm{nC}$. Hierdie spesifieke ontwikkeling hou onderskeidelik verband met die eenheid-in-die-plaaslike-gemeente en in-die-algemene-kerk:

If there was any visible symbol of unity it was epitomized in the figure of the bishop associated with other bishops. Cyprian in his conference essay On the unity of the catholic church insisted that there is only one church. This church is found where the bishop is. Ignatius had said this earlier, but he was speaking about the individual congregation. Cyprian applied this to the church at large. That is, he said that a group can call itself 'church' only as it has a bishop who has been properly ordained and who is in unity with the other bishops of the church. There is, therefore, only one church. All who were not part of this empirical reality were not considered church (Oetting 1964: 51).

Dit is opvallend dat Ignatius in sy brief aan die gemeente in Smirna die eerste persoon in die vroegste kerk was wat uitdruklik die term 'katolieke kerk' gebruik het (kyk Oetting 1964: 44-45). Soos dit in die verwysing na Ignatius in die aanhaling hierbo gesien kan word, het hy die plaaslike gemeente in die oog gehad. Hierdie besondere opmerking in sy brief aan die gemeente is daarom van groot belang. Oetting (1964: 44) vertaal dit soos volg:

Where the bishop is present, there let the congregation gather, just as where Jesus Christ is, there is the Catholic Church.

So gesien, konkretiseer die eenheid in beginsel op dieselfde manier in sowel die individuele gemeente as in die algemene kerk. Dis die rede waarom ek aan die begin van my betoog gesê het dat ek die spore in die Nuwe Testament van 'n ontwikkeling van 'n eenheid-van-die-kerkbegrip verstaan as aanduidinge van die eis, enersyds om kontinuïteit in die oordra van die evangelie en andersyds om die gemeenskap van die gelowiges. Die Griekse woord wat met 'gemeenskap' vertaal word, naamlik koinōnía, word juis in die Nuwe Testament gebruik om die gemeenskaplike deelhê aan iets - aan Christus en aan sy evangelie mee uit te druk. Ferdinand Hahn (1986b: 120) formuleer dit soos volg: 
Hier ist nicht die menschliche Zusammengehórigkeit und Verbundenheit der primäre Gesichtspunkt, sondern die Vorstellung des 'Teilhabens an'....

Die eenheid-van-die-kerk is derhalwe iets wat ten diepste betrekking het op die verkondiging-gebeurtenis wat in die samekoms van die gemeente plaasvind. Die gemeenskaplike deelhê aan hierdie gebeurtenis is die beoefening van die gemeenskap van die gelowiges. Op hierdie manier konkretiseer die eenheid van die één, heilige, algemene kerk, gegrond op die woorde van die apostels.

Dit was Karl Barth wat gesê het dat om saam-met-die-gemeente te wees is om saam-met-die-medemens te wees.

... our 'I believe in the Holy Spirit' would be empty if it did not also include in a concrete, practical, and obligatory way the 'I believe one Holy Catholic and Apostolic Church.' We believe the Church as the place where the crown of humanity, namely, man's fellow-humanity, may become visible in Christocratic brotherhood. Moreover, we believe it as the place where God's glory wills to dwell upon earth, that is, where humanity - the humanity of God - wills to assume tangible form in time and here upon earth (Barth 1972: 65).

Die ontstaan van die eenheid-in-die-instituut hang saam met die verskynsel dat die geestelike kerk in die vierde eeu staatskerk geword het met die pous as hoof van die kerk en van die staat. Hierdie 'eenheid' stry teen die Gees. Dit is mens-onderdrukkend en ontneem die kerk sy eg-menslikheid as geestelike beweging.

\section{DIE KERK AS EKKLĒESÍA}

Ons het reeds gesê dat vóór Jesus die kerk se wortels in die Ou Testament lê. Die vroegste kerk self het hom heilshistories op een of ander manier as die voortsetting gesien van die volk Israel as die volk van God in die Ou Testament. In die lig van die moderne semantiek is dit egter onhoudbaar om hierdie heilshistoriese kontinuum te beredeneer aan die hand van die gebruik van die woorde qāhāl en ekklēsía. Tog is dit met betrekking tot ons vrae oor die begin van die kerk wel deeglik relevant om te probeer agterkom waarom die vroegste kerk veral die woord ekklessia as selfaanduiding begin gebruik het. In der waarheid is 
ons van mening dat die antwoord op hierdie vraag ons kan help om die uniekheid van die Christene as beweging te midde van die heterogene Joodse gemeenskap in die eerste eeu beter te begryp.

Die Hebreeuse woord $q \bar{a} h \bar{a} l$ word in die Septuagint met onder andere ekklèsia en sunagōgē vertaal. 'ẹda word in die Septuagint hoofsaaklik met sunagōge weergegee, maar nie met ekklessia nie. Beide hierdie Griekse woorde kom in sekere kontekste in die Septuagint voor in die betekenis 'godsdienstige versameling van mense'. In die Nuwe Testament maak dié twee woorde deel uit van die semantiese woordveld 'sosiogodsdienstige groepering van mense'. Die ander Griekse woorde wat onder andere ook hierop betrekking het, is sōma (= liggaam), laós (= volk) en poimnion (= kudde). Die woord ekklèsia, in onderskeid met die semantiese komponente van die genoemde woorde, dien as aanduiding van 'n groep Christene wat gereeld formeel vir godsdiensoefening bymekaar kom. Dit kan verwys na 'n spesifieke groep, soos byvoorbeeld in Korinte (1 Kor 1: 2), of na die 'ganze Kirche als Einheit', soos byvoorbeeld in Matteus 16: 18 (Conzelmann 1977: 394). Laasgenoemde verwysing moet glad nie geïnterpreteer word as aanduiding van 'n 'institusionele eenheid' nie, selfs nie in die sin van 'algemene kerk' nie.

Ons het vroeër daarop gewys dat dit eers Ignatius was wat in die literatuur aan ons bekend, die uitdrukking 'algemene kerk' vir die eerste keer gebruik het. Die gebruik van ekklēsía in Matteus 16: 18, en ook in Galasiërs 1: 13 en Filippense 3: 6, kan vergelyk word met die gebruik van ekklēsía in onder andere 1 Makkabeërs 2: 56 en 4:59 waar die frase pâsa hē ekklēsia Israēl betrekking het op die 'Gesamtgemeinde Israels' (Schrage 1963: 191). Hiermee is nie in die moderne sin van die woord 'n entiteit in die gesigsveld soos ò 'kerkverband' ò 'universele/ algemene kerk' of 'onsigbare kerk' nie. Wat waarskynlik met die woord ekklēsía in sy kollektiewe gebruik uitgedruk was, is dat wat van 'n spesifieke konkrete gemeente gesê kan word, ook op ander (konkrete) gemeentes van toepassing was. Rost (1938: 155) formuleer dit soos volg: 'Der Teil repräsentiert das Ganze, und das Ganze schliesst den Teil ein.' Volgens Berger (1976: 188) is die komponent 'groep/versameling' in die gevalle met 'n kollektiewe verwysing beslis nie losgelaat nie, hoewel dit lyk dat dit in hierdie gevalle nie slegs gaan 'um eine zum Gottesdienst versammelte Gemeinde' nie.

Wat ons aandag vra, is die vraag na die rede waarom die eerste Christene so baie die woord ekklēsía gebruik het om hulle soort groepering aan te dui en nie, behalwe in die geval van Jakobus 2: 2 wat die Nuwe Testament betref, die woord sunagōge nie. Beide hierdie 
woorde is tog in die Septuagint gebruik om onder andere na die volk Israel as ' $n$ godsdienstige versameling van mense te verwys.

Dit is op grond van Handelinge 14: 43 duidelik dat die woord sunagōge se betekenismoontlikheid as godsdienstige byeenkoms wel in die vroeë kerk, naas die voorkoms daarvan in die Septuagint, bekend was. Wolgang Schrage het oortuigend aangetoon dat die ou skolastiese argument (kyk Richardson 1958: 284-286) nie standhou dat ekklēsía die heilshistoriese voortsetting van die Ou-Testamentiese qāhal JHWH is nie.

... die Wahl von ekklēsía ist primär nicht durch das Bewusstsein bestimmt, dass sich die Urkirche in heilsgeschichtlicher Kontinuität zu Israel und damit als legitime Nachfolgerin des altesamentlichen Budesvolkes verstand (Schrage 1963: 188).

Benewens bogenoemde bydrae van Schrage het James Barr (1961: 119-129) in die lig van moderne semantiese insigte die redes beredeneer waarom die Griekse woord ekklēsía nie sonder meer etimologies teruggevoer moet word na die Griekse werkwoord kaléō (= om te roep) en vandaar na die stam gol (= stem) in die Hebreeus nie. Daar is dus nie grond vir die bewering dat die woord 'kerk' op grond van sy sogenaamde etimologiese oorsprong in die uitdrukking 'die stem/woord van God', 'uitgeroepenes' sou beteken nie. Die uniekheid van die kerk in terme van ander samelewingsverbande, en ook in terme van ander godsdienste, lê nie in die etimologie van die woord ekklēsía nie. Eweneens moet ons die stelling dat die kerk aan die Here behoort, nie etimologies grond op 'n siening dat die woordjie 'kerk' (ofte wel church, Kirche, kirk - kyk Richardson 1958: 284, voetnota 3) afgelei is van die Griekse term kuriakós wat dan sou beteken 'om aan die Kúrios te behoort' nie.

KL Schmidt (1968: 516) het 'n sterk saak daarvoor uitgemaak dat die woord ekklèsia vir die eerste keer deur die Joods-Hellenistiese Christene gebruik is as aanduiding van die eie aard van die Christelike beweging in onderskeid met die Joodse sunagōgaí. Hierin het hy baie steun ontvang (vgl o a Hahn 1986b: 130-131). Hierteenoor meen Rost (1938: 156) dat Jesus self die woord ekklēsia vanuit die Ou Testament ontleen het en nie vanuit die Hellenisme nie. Sonder om nou op al die argumente daarteen in te gaan, kan iemand soos Rost egter nie heeltemal toegegee word nie. Sy standpunt veronderstel 'n te kompartementele skeiding tussen Jodedom en Hellenisme op die eerste-eeuse Palestynse bodem. 
Much of what is said about the differences between various forms of primitive Christianity is undoubtedly true. The danger of dividing Christianity into chronological compartments or phases with regard to Judaism versus Hellenism, however, is that it presents on oversimplification of a very complex situation. The first century setting of primitive Christianity cannot any longer be seen in terms of Judaism versus Hellenism. Hellenism became part and parcel of the world of that time. Even Palestine underwent radical changes as a result of the spread of Hellenistic ecumenism (Vorster 1981: 51-52).

Wat ons wil betoog, is juis dat hierdie radikale veranderinge wat rondom die eerste eeu vanweë die Helleniseringsproses plaasgevind het en waarna Willem Vorster in die aanhaling hierbo verwys het, die begin van die kerk beïnvloed het. Die rede vir die voorkeur van die term ekklèsia bo sunagōge in die vroegste kerk kan myns insiens ook nie losgemaak word van die situasie nie. Enersyds was dit 'n situasie wat gekenmerk was deur die invloed van die Hellenisme op die Jodedom en andersyds ' $n$ situasie waarin die Christene hulle in konflik met die sinagoge en die Romeinse wêreldryk bevind het. Die konflik tussen die Christene en die amptelike sinagoge het ontspring in die manier waarop die Christene ' $n$ openheid vir die Helleniste gehad het en waarop proseliete toegelaat is sonder dat hulle erg gehad het aan die Joodse tradisies. Hiermee saam was die verkondiging van die menswording en opstanding van Jesus 'n ernstige struikelblok vir die amptelike Jodedom.

Hellenisering het dus konflikte meegebring. Die bestaan van die Aleksandrynse Jodedom by die aanbreek van die Nuwe-Testamentiese periode is ' $n$ aanduiding daarvan dat dié konflikte reeds vir Jesus op Galilese bodem en vir die eerste Christene ' $n$ aktuele aangeleentheid was. In hierdie verband is dit daarom van belang om na te gaan hoe die Aleksandrynse Jood, Philo (wat deur Rost die 'Septuagint-Jood' genoem word vanweë Philo se gebruik van die Septuagint), die woorde ekklessia en sunagōge aangewend het.

Rost (1938: 146-149) het so 'n studie gedoen. Hy het bevind dat sunagōge net twee keer by Philo voorkom. Beide kere het dit die betekenis 'sinagogegebou'. Hierdie betekenismoontlikheid kom ook via die Aramese kenišță ook in die Mishna voor. Met so 'n betekenis was dit vir feitlik alle praktiese redes onmoontlik vir Joodse Christene en Joods-Hellenistiese Christene om hulleself as groep daarmee aan te 
dui (Rost 1938: 144-145; 156). Wat ekklēsía betref, onderskei Rost drie gebruiksareas. Die een is ' $n$ tipe Hellenistiese byeenkoms wat betrekking het op 'n byeenkoms van Griekse gode of burgers van Hellenistiese stadstate. Tweedens het dit betrekking op die sogenoemde Sinaïversameling in die $\mathrm{Ou}$ Testament en derdens is daar Philo se allegoriese gebruik daarvan na aanleiding van Deuteronomium 23: 1-8. Dis baie belangrik om daarop te let dat Philo die woord ekklēsia nie met verwysing na die Joodse gemeente van sy tyd aangewend het nie.

Watter van hierdie resultate kan vir ons vraagstelling van betekenis wees? Ons het reeds hierbo daarop gewys dat Rost (1938: 154) van mening is dat die Nuwe-Testamentiese gebruik van ekklessia vir die Christene as groep sy oorsprong het in die Ou Testament en nie in die Hellenisme nie. Hiermee het ons probleme gehad. Sy opmerking is net gedeeltelik reg. Die oorsprong van die Nuwe-Testamentiese gebruik moet myns insiens gesoek word in die Aleksandrynse Jodedom se gebruik van die Ou Testament, dit wil sê in die Hellenistiese Jodedom. Tog is Rost (1938: 151) aan die ander kant heeltemal korrek deur te sê dat Deuteronomium 23: $1-8$ in hierdie verband ' $n$ baie groot rol gespeel het. Die Hebreeuse uitdrukking qāhal JHWH word in hierdie Ou-Testamentiese passasie meer as een keer gebruik. In die $\mathrm{Ou}$ Testament het qāhāl betrekking op 'n 'Aufruf zu einer Versammlung' (Rost 1938: 31).

Aufgebot umfasst mit Ausnahme von Jer. 44, 15 und Esr. 10,1; Neh. 8, 2-17 nur den ' $\bar{a} m$, die Gesamtheit der männlichen Volbürger. Die ausgenommen Stellen ziehen auch Frauen (und Kinder) zum Aufgebot heran ... Zweck des Aufgebots ist der Zusammentritt der Mannschaft zur kultischen Feier, zur Gerichtszitzung oder zum Heerzug (Rost 1938: 31-32).

In Deuteronomium 23: $1-8$ vind ons die bepalinge oor wie lid mag word van die $q \bar{a} h \bar{a} l J H W H$ as volksvergadering en wie nie. Onder andere was die volgende persone vir altyd uitgesluit: iemand wie se geslagsorgane verbrysel was of wat ontman is (LXX- thladias kai apokekomménos), kinders uit 'gemengde huwelike', Ammoniete en Moabiete. Kinders uit die derde geslag Edomiete en Egiptenare mag egter lid geword het. Die herhaaldelike gebruik van qāhăl in hierdie perikoop is in die Septuagint elke keer met ekklēsía weergegee.

Terwyl die woord sunagōge e, naas die tegniese betekenis van 'sinagogegebou' wat dit by Philo begin kry het, elders steeds op die partikularisties-Joodse eksklusiewe gemeente gedui het en normaalweg as die 
hoi Ioudaîoi bekend gestaan het (kyk Rost 1938: 156; vgl ook die Nuwe Testament), het die woord ekklēsia se gebruik in hierdie verband egter 'n ontwikkeling ondergaan. Hierdie verandering ten opsigte van verwysing het onder die invloed van die universalisties-georiënteerde Hellenisme plaasgevind. Dit kan gesien word in enersyds Philo se allegoriese uitleg van Deuteronomium 23: 1-8 en andersyds die Kronistiese geskrifte, naamlik Esra en Nehemia. Laasgenoemde geskrifte het in die oproep tot die kultiese byeenkoms (aangedui in die Septuagint met die woord ekklessía) die vrouens en kinders nie meer uitgesluit nie (Rost 1938: 156). Philo self het in sy allegoriese uitleg van Deuteronomium 23: 1-8 die eksklusivisme ten opsigte van die Ammoniete en Moabiete toegepas op politeïste en ateiste, terwyl hy die verwysing in Deuteronomium 23: 8 na die toelating van die derde geslag Egiptenare en Edomiete aktualiserend toegepas het op die inkoms van die proseliete in die ekklésía (Berger 1976: 189-191).

Dié deurbreking van die partikularisme het in die Nuwe Testament op verskillende maniere neerslag gevind. Waar die eksklusivisme van Deuteronomium 23: 1-8 op die Jerusalemse tempel toegepas is en selfs die uitleg van die tempel se aparte voorhowe (vgl Van Selms 1969: 171) bepaal het, daar is dit opvallend dat Matteus implisiet kritiek daarop uitoefen. Matteus vertel nie net van die skeur van die voorhangsel van die tempel (Matt 27: 51) en die Christologiese belydenis van 'n nie-Jood (Matt 27: 54) na aanleiding daarvan nie. Matteus vertel ook dat Jesus blindes en kreupeles in die tempel gesond gemaak het (Matt 21: 14) en dat kinders in die tempel (Matt 21: 15) Hom as die Seun van Dawid geloof het. Die vertellinge in Handelinge oor die genesing van verlamdes en kreupeles in ' $n$ Samaritaanse stad (Hand 8: 7) en die gelowigword en doop van mans èn vrouens (Hand 8: 12), sowel as oor die ontmande Etiopiër se bekering en doop (Hand 8: 26-39; vgl ook die verwysing na Klemens van Aleksandrië in Berger 1976: 196, voetnota 190 ), kan ongetwyfeld ook in verband met die deurbreking van partikularisme vermeld word. Net so steek daar baie meer in die allegorese van Efesiëres 5: 27 waar daar oor die ekklēsia gesê word dat die kruisdood van Christus meegebring het dat die kerk hagia kai amōmos (= 'heilig en onberispelik') is. Dit is woorde wat moontlik sinspeel op die 'verminking' (thladias kai apokekomménos) waarvan Deuteronomium 23: 2 praat en wat juis die rede was waarom so 'n persoon nie lid van die ekklésia kon wees nie. Die kerkvader Origines (kyk Berger 1976: 190 , voetnota 120) het klaarblyklik op grond hiervan die kerk van die sinagoge onderskei deur eersgenoemde hagia kai amōmos te noem. Wat 
meer is, hierdie Efesiërteks was die teksberoep vir die belydenis dat die kerk 'heilig' is (Oetting 1970: 50, voetnota 11).

Hoewel die woord ekklesia nie die enigste Griekse woord is waarmee die Christene as religieuse groepering uitgedruk was nie, is die vroegste Christene se gebruik van die woord, in die lig van die voorafgaande, ' $n$ aanduiding van die gemeenskaplike deelhê van Jood en nie-Jood aan Christus. Daarby moet daar onthou word dat die byeenkoms waarop ekklēsía betrekking het, die formeel-erediens-versamelde gemeente was. Hoewel die wortels van ekklēsía se gebruik as aanduiding van die Christelike gemeente na my oordeel dus in die Aleksandrynse Jodedom lê, soos dit by Philo se allegoriese uitleg van Deuteronomium 23: 1-8 na vore gekom het, is dit onwaarskynlik dat die verskynsel van 'n formeel-erediens-versamelde gemeente in die periode voor-pase moontlik kon gewees het. Daarom moet ons instemming met die volgende uitspraak van Trilling (1978: 68) betuig:

Die historische Wahrscheinlichkeit, das Jesus eine Kirche 'gedacht' - 'gewollt' oder 'gegründet' - habe, ist aüsserst gering....

Die bekende en pregnante opmerking van Alfred Loisy (in Trilling 1978: 68) word in hierdie verband dikwels aangehaal:

Jésus annonçait le royaume, et c'est I'eglise qui est venu (= 'Jesus het die koninkryk aangekondig, en wat gekom het, is die kerk').

Tog moet die verbondenheid van die kerk met die Jesus-saak onverswak gehandhaaf word.

\section{KERK EN KONINKRYK}

Die Jesus-saak het, baie kort gestel, te make met die realisering van die koninkryk van God. In en deur Jesus Christus is God regerend, rigtend en reddend teenwoordig. Die aard van Jesus se geboorte, gehoorsame lewe, kruisdood en opstanding is die wyse waarop die verwagting dat God regeer, realiseer het. En die verkondiging van die na-pase geloofsgemeenskap dat die mens, in die Gees deur die geloof, aan Christus se weldade deel kan hê, is steeds die wyse waarop dié verwagting in die lewens van mense kan realiseer. Dit bring ons voor die kwessie rondom die verhouding tussen koninkryk-kerk te staan.

Soms wil dit in die Nuwe Testament lyk asof die koninkryk van God 'n blote toekomstige saak is wat eers na die verbygaan van die aardse 
bedeling sal realiseer. Dit is ' $n$ feit dat só 'n opvatting in die apokaliptiek voorgekom het. Daar is Nuwe-Testamentici wat meen dat Jesus self nie dié opvatting gehuldig het nie (kyk Hahn 1986a: 192-194), maar wel 'n 'konsekwente eskatologie'. Dit kom daarop neer dat Hy nie verwag het dat sy onderrig oor die koninkryk van God eers in die toekoms sal realiseer nie, maar reeds in en deur sy lewe, dood en lewe. So gesien moet die skerp skeiding tussen die teenswoordige aardse bedeling en die toekomstige koninkryk van God beskou word as die produk van die apokaliptiese strominge in die Jodedom wat Christene ingesluit het. Dit het ook meegebring dat die na-pase Jesus-beweging wat 'kerk' genoem is, later in die eerste intensiewe studies van die apokaliptiese tekste aan die einde van die negentiende eeu gesien is as die menslike negatiewe teenpool van God se koninkryk wat nog in die toekoms lê. So 'n opvatting hou nie rekening met die teologiese en antropologiese betekenis van die samehang tussen inkarnasie en opstanding nie.

Hoewel die kerk nie as die negatiewe teenpool van die koninkryk van God beskou moet word nie, is die kerk egter ook nie identies aan die koninkryk nie.

Die Basileia wird niemals, auch nicht in einer ferner Zukunft, mit der Kirche identisch. Sie 'entwickelt' sich auch nicht nach Wachstums - oder Evolutionsgesetzen innerhalb der Geschichte. Sie wird auch nicht - im strengen Sinn - durch menschlichen Einsatz vorangebracht. Sie bleibt in Gottes Souveränität und in seiner Macht der Freiheit - auch gegenüber der Kirche oder den Kirchen! Und dennoch ist sie gegenwärtig, unser Zeit präsent (Trilling 1978: 71).

Hoe realiseer God se koninkryk dan steeds in ons tyd? Wolfgang Trilling is prinsipieel korrek deur te sê dat dit nie die mens is wat met sy daad die koninkryk van God laat realiseer nie. Dit is die daad van God deur sy Gees in en deur die kerk. Tog gaan die koninkryk van God die kerk te bowe, soos die openbaring van God die Woord te bowe gaan. God se regering strek hom uit oor alle sfere van die samelewing - ook oor dié buite die ruimte van die kerk. Teokrasie beteken dat God regeer - oral en altyd. God regeer deur sy Woord en deur sy Gees. Sy Woord en sy Gees heers in die hart van elke Christen. Dienooreenkomstig behoort die Christen sy keuses te maak waar hy hom ook al bevind en handel. En die plek waar Christene handel, is natuurlikerwys meer in ander samelewingsverbande as in die samekomste van die gemeente. Daar is egter net één plek waar die Christen hoor wat God in 
sy koninkryk wil, en dit is in die formeel-erediens-versamelde gemeente waar die gelegitimeerde verkondiger, in wie die Gees woon en op wie die hande van die gelegitimeerde voorgangers gelê is, die wil van God verkondig. Die status van dié gelegitimeerde verkondiger kan nie beter beskryf word as met die uitdrukking primus inter pares nie. Dit wat God in sy koninkryk wil, is ten diepste dus iets wat in die verkondiging gehoor word. Dis in dié sin van die woord dat die Augustynse spreuk, extra ecclesiam nullam salus est, waar is. Vanuit die verkondiging versmelt die wil van God in die wil van mense. Die verkondiging begelei die gemeente se tog in die wêreld. Hierdie roeping vervul die kerk deur draer van die Woord te wees. Dit is daarom dat die kerk hom van die aanvang van sy institusionalisering af rondom die Skrifte georganiseer het (vgl 1 Tim 3: 15-16a). Die Gees van God werk in onlosmaaaklike verband met die kerk deur sy Woord. Maar omdat die heil van die mens meer is as blote aardse welsyn, gaan die koninkryk van God die kerk so ver te bowe dat wanneer die kerk by die voltooiing van die tyd ophou om kerk te wees, God steeds sal regeer. Anders as die koninkryk, is die kerk volledig menslik, gebonde aan mense se bestaan in die aardse bedeling. Hy wat ' $n$ wensbeeld van die kerk nahou, kan die kerk se menslikheid nie positief ag nie en kan derhalwe ook nie die beperkthede van die kerk verwerk nie.

\section{GEVOLGTREKKING}

1. Die kerk se wese lê, Nuwe-Testamenties gesien, in sy verbondenheid met die Jesus-saak. Die Waarheid vir die kerk is Jesus Christus. In en deur die verkondiging vervul die kerk sy roeping om draer van die Waarheid te wees.

2. Die koninkryk van God gaan die kerk vooraf soos die 'verkiesing', die 'verbond' en die 'geloof' die 'werke' voorafgaan en tog kan die een nie van die ander geskei word nie.

3. Die kerk was die geestelike beweging in 'n tyd toe die politieke rigting dié van universalisme was. In 'n sekere sin was dit die stukrag agter die verspreiding van die kerk. Ongelukkig het dit veroorsaak dat die kerk òf as die geestelike keerkant van die politiek gesien word òf as deel van die politiek, soos dit sedert die vierde eeu, vanweë 'n vervreemding met die Jesus-saak en 'n verpolitiseerde eenheidsvisie wat in die instituut en die pous gesetel was, verword het. In die Nuwe-Testamentiese en vroeg-patristiese periode was dit 
nie die geval nie. Die kerk het gestry teen die beeld dat hy 'n politieke beweging sou wees (kyk Hand 17: 7; 25: 8), juis op grond van sy saak, naamlik die Jesus-saak wat in en deur sy kerugma gedra is. Die Nuwe-Testamentiese beeld van die kerk, teen die agtergrond van die polities-universele Romeinse wêreldryk, is dié van die dienskneg en vervolgde. Waar die Jodedom sowel as die Romeinse ryk dit so aanvaar het, het die kerk hierdie vergunde ruimte as sy 'vrede' gesien (kyk Hand 9: 31 en 28: 31).

4. Vanuit veral die goddelike wonder van die inkarnasie en die opstanding van Jesus, moet die kerk se kontinuïteit asmede sy diskontinuïteit met enersyds die Jodedom en andersyds die Hellenisme, te midde van 'n Joods-Hellenistiese situasie binne die Romeinse wêreldryk gesien word. Teen die agtergrond van hierdie konflik-potensiële situasie was Joodse partikularisme en Hellenistiese universalisme nie alternatiewe nie. In sy partikulêr-Joodse gerigtheid was die kerk oop na 'n universeel-Hellenistiese gerigtheid. Die konflik wat hieroor ontstaan het, is gehanteer met die oproep om die gemeenskaplike deelhê aan die Jesus-saak te laat uitmond in die koinōnía van die gelowiges. Hierdie 'gemeenskap' word primêr beleef in die formeel-erediens-versamelde gemeente deur die gemeenskaplike deelhê aan die verkondiging-gebeurtenis. Dis klaarblyklik die rede waarom die term ekklēsía so uiters funksioneel vir die Joods-Hellenistiese Christene was om hulleself as groep daarmee aan te dui.

5. 'Eenheid' en 'algemeenheid' is geestelike begrippe en het betrekking op leer en lewe in verbondenheid met die Jesus-saak. Aan die een kant het dit betrekking gehad op die kontinuïteit in die oorlewering van die apostoliese woord en aan die ander kant op die gemeenskap van die 'heiliges' in onbelemmerde spontane liefde. Die kerk is ' $n$ geestelike bestuurstelsel - ofte wel 'n oikodomouménē begelei deur die Gees (kyk Hand 9: 31; Ef 4: 3-4; Gal 5: 25; 1 Kor 12: 7). Die oorgang van die charismatiese bestuurstelsel na die amps-bestuurstelsel laat hierdie 'geestelikheid' nie los nie, maar dien die 'eenheid' en 'gemeenskap', soos hierbo verstaan.

6. Juis die geestelike karakter van die kerk is die kerk se menslikheid gesien sowel in terme van die menswording van Jesus as in terme van sy Gees wat verskillende gawes uitdeel (1 Kor 12) na gelang van die mense in die kerk, ter wille van die opbou in die liefde; die geestelike kerk is soos ' $n$ simfonie. Hierdie eenheid op grond van die veelheid word baie effektief deur die Nuwe-Testamentiese beeld van 
die sōma (= liggaam) uitgedruk. In dié sin van die woord kan die woorde ekklessía en sōma dieselfde verwysing betreffende die verhouding partikularisme-universalisme hê.

7. As die ekumeniese gesprek tussen kerke nie is soos die gemeenskap van individuele gelowiges in die gemeente nie, het ons van die kerk 'n superkerk met supermense gemaak. En dit is 'n wêreldontwykende illusie, want dit is ' $n$ wensbeeld van wat 'kerk' is. Ons moet leer om teologiese nuanses en wyduiteenlopendheid in die ekumene te hanteer soos ons in die natuur met die verskeidenheid van die skepping werk en soos ons in die pastoraat die konflikte onder mense hanteer - nie dat daar geen verskeidenheid meer sal wees of konflik sal opduik nie, maar dat daar gemeenskap met mekaar sal wees. So is ons menslike kerk en terselfdertyd 'n Gees-beheersde kerk.

8. Die kerk sal moet wal gooi teen die teleologiese geneigdheid in die politiek en die kultuur, en deesdae ook in die ekologie, wat die gees van holisme genoem kan word. 'n Eksponent hiervan skryf soos volg (Fritjof Capra, in Boelema 1987: 4):

Alles is één. Alles stroomt. ledereen en alles is met elkaar verbonden .... Alles is één. $\mathrm{Er}$ is zoiets als een energetische eenheid van het heelal ....Wij constateren een gebrokenheid, waarmee wij moeten afrekenen en daarom moeten wij komen tot een eenheid, een heelheid, een wêreldomvattend syncretisme van theologieën, religies, filosofieën ....

Maar die baba moet nie saam met die badwater weggegooi word nie. Om die gees van holisme weg te wens is om weer eens die teenswoordige werklikheid te ontvlug. En dis waarteen ons dit het vanuit die perspektief van die menslikheid van die kerk. Dit lyk asof die teologie hom in die oorgang na 'n nuwe kenteoretiese paradigma bevind, wat wesenlik deur die filosofie van die holisme beïnvloed word. In ons ekklesiologiese nadenke sal ons hiermee rekening moet hou. Aan die een kant moet ons ons nie skuldig maak aan die hermeneutiese dwaling van misplaaste konkretisering deur te wil voorhou dat die holistiese denke 'n Bybelse idee is nie. Aan die ander kant moet ons egter ook nie die waarheidsmomente van die nuwe rigting ontken of summier verwerp nie. Myns insiens lê die antwoord wat in die kerk gegee behoort te word in die erkenning en benutting van die feit dat daar ' $n$ verskeidenheid van mense, volke en geloofsgemeenskappe spontaan ontstaan het en steeds bestaan. 
En dit sal nie anders kan nie as dat hierdie erkenning spontaan sal oorgaan in die herkenning van volks- en nasionale kerke. Waarom moet hierdie verskynsel ontken, as sondig verklaar en weggewens word? Maar ongelukkig het sulke geïnstitusionaliseerde strukture in Suid-Afrika daartoe gelei dat die spontante gemeenskap van gelowiges binne die samekomste van die gemeente belemmer geraak het. Ek kan hierdie saak nie anders sien nie as dat dit die gevolg is van die ou-ou dwaling, naamlik dat die kerk steeds as die geestelike keerkant van die politiek beskou word. Hieraan moet ons werk, want dit stem nie ooreen met dit wat die Nuwe Testament vir ons oor die kerk sê nie. Die getuienis van die Nuwe Testament is dié van 'n geskiedenis van versoenende verskeidenheid en een wat aanleiding gegee het tot die belydenis dat die kerk één, heilig en algemeen is, en gegrond is op die apostoliese woord.

Maak front teen die wensbeeld van die één institusionele kerk, maar raak ook ontslae van die belemmeringe wat die spontane gemeenskap van die gelowiges verhinder! Net soos die holistiese illusie van die één kerk, is ook die belemmering van die gemeenskap van die gelowiges 'n ont-mensliking van die kerk.

\section{Literatuurverwysings}

AALDERS, GJD 1985. Synagoge, kerk en staat in de eerste vijf eeuwen. Kampen: Kok.

BARR, J 1961. The semantics of Biblical language. Oxford: Oxford University Press.

BARTH, K 1932. Die Theologie und die Mission in der Gegenwart. Zwischen den Zeiten 10, $189-215$.

BARTH, K 1960. Die Lehre von der Versöhnung, in Die Kirchliche Dogmatik, Vierter Band, Erster Teil. 2 Aufl. Zürich: EVZ-Verlag.

BARTH, K [1960] 1972. The humanity of God. Transl by JN Thomas. Tenth printing. Richmond: John Knox.

BAUR, PC 1860. Das Christentum und die christliche Kirche der drei ersten Jahrhunderte. Zweite, neu durchgearbeitete Ausgabe. Tübingen: Mohr.

BERGER, K 1976. Volksversammlung und Gemeinde Gottes: $\mathrm{Zu}$ den Anfängen der christlichen Verwendung von 'ekklesia'. ZThK 73, 167-207.

BLEI, K 1986. Schillebeeckx, pleiter voor een menselijker kerk, in Evangelische Commentaar 12 September 1986 , bl 10-13.

BOELEMA, J 1987. Op zoek naar holisme: Een nieuwe cultuur in opkomst? Getrouw 40, $3-6$.

BOTHA, A 1987. 'n Volksteologie. NGTT 28, 119-124.

CONZELMANN H 1977. Geschichte des Urchristentums, in Conzelmann, H \& Lindemann, A, Arbeitsbuch zum Neuen Testament, 282-432. 3. Aufl. Tübingen: Mohr.

CULLMANN, O 1986. Einheit durch Vielfalt. Tübingen: Mohr.

ELLIOT, JK 1987. Oorsigartikel: Rowland, C 1985. Christian origins. London: SPCK. SJTH $40,149-151$.

HAHN, F 1986. Exegetische Beiträge zum ökumenischen Gespräch: Gesammelte Aufsätze, Band L Göttingen: Vandenhoeck. 
HAHN, F 1986a. Die Petrusverheissung Mt 16, 18f. Eine exegetische Skizze, in Hahn 1986: 185-200.

HAHN, F 1986b. Die Einheit der Kirche und Kirchengemeinschaft in Sicht, in Hahn 1986: 116-158.

HAHN, F 1986c. Neutestamentlicher Grundlagen für eine Lehre vom Kirchlichen Amt, in Hahn 1986: 159-184.

HAHN, F 1986d. Das Problem des Frühkatholizismus, in Hahn 1986: 39-56.

HAHN, F 1986e. Thesen zur Frage einheitsstiftender Elemente in Lehre und Praxis des urchristlichen Herrenmahls, in Hahn 1986: 232-241.

HEMSTEDE, H 1987. Omgaan met konflikte, in Weekbulletin van het Persbureau der Nederlandse Hervormde Kerk 26 Maart 1987, bl 8.

KÄSEMANN, E 1963. Paulus und der Frühkatholizismus. ZThK 60, 75-89.

KÄSEMANN, E 1969. Unity and multiplicity in the New Testament doctrine of the church, in New Testament questions of today, 252-259. London: SCM. (New Testament Library.)

KATZ, ST 1984. Issues in the separation of Judaism and Christianity after $70 \mathrm{CE}$ : A reconsideration. JBL 103, 43-76.

MARSHALL, IH 1977. The origins of New Testament Christology. Second printing. Leicester: Inter-Varsity Press.

OETTING, W 1964. The church of the catacombs: An introduction to the surging life of the early church from the apostles to $A D$ 250. Based on first-hand accounts. Saint Louis: Concordia Publishing House. (Church and History Series.)

PONT, AD 1987. Die vrye kerk: Enkele opmerkings oor die herkoms en inhoud van die opvatting. HTS 43, 25-46.

RICHARDSON, A 1958. An introduction to the theology of the New Testament. New York: Harper \& Row.

ROST, L 1938. Die Vorstufen von Kirche und Synagoge im alten Testament: Eine wortgeschichtliche Untersuchung. Stuttgart: Kohlhammer. (BWANT 76.)

ROWLAND, C 1985. Christian origins. London: SPCK.

SCHMIDT, KL 1968. s v ekklēsía. TDNT, Vol III. Third printing. Grand Rapids: Eerdmans.

SCHRAGE, W 1963. 'Ekklēsía' und 'Synagōgē': Zum Ursprung des urchristlichen Kirchenbegriffs. ZThK 60, 178-202.

SPOELSTRA, B 1986. Het ons kerkwees in strukture gestol? HTS 42, 94-109.

STARK, R 1986. Jewish conversion and the rise of Christianity: Rethinking received wisdom, in Richards, KH (ed), Seminar Papers: Society of Biblical Literature, 314-329. Atlanta: Scholars Press.

STENDAHL, K 1959. s v Kirche: Im Urchristentum. RGG, Dritter Band. 3. Aufl. Tübingen: Mohr.

TRILLING, W 1978. 'Implizite Ekklesiologie': Ein Vorschlag zum Thema 'Jesus und die Kirche', in Die Botschaft Jesu: Exegetische Orientierung, 57-72. Freiburg: Herder.

VAN SELMS, A 1969. Jeruzalem door de eeuwen heen: Van vóór koning David tot generaal Dayan. 2de Druk. Baarn: Hollandia.

VAN WYK, DJC (red) 1978. Stemme uit die verlede: Volkereverhoudings in Suid-Afrika. Pretoria: HAUM.

VORSTER, WS 1981. On the origins of Christianity: A religio-historical perspective, in Vorster, WS (ed), Christianity among the religions, 36-56. Pretoria: University of South Africa. (Miscellanea Congregalia 19.). 